Vol. 10. No. 1. Tahun 2022

\title{
PENGARUH PAJAK PENGHASILAN BADAN, CURRENT RATIO DAN KINERJA PERUSAHAAN TERHADAP RETURN ON ASSET PADA PERUSAHAAN JENIS CONSUMMER GOODS YANG TERDAFTAR DI BEI PERIODE 2018-2021
}

\author{
SAHRUL IHSAN \\ Fakultas Ekonomi Universitas Gunung Rinjani \\ E-mail : sahrulihsan751@gmail.com
}

\begin{abstract}
ABSTRAK
Penelitian ini bertujuan untuk mengetahui pengaruh antara pajak penghasilan badan, current ratio dan kinerja perusahaan terhadap return on asset pada perusahaan industri jenis consummer goods yang terdaftar di bursa efek Indonesia periode 2018-2021.Penelitian ini merupakan penelitian kuantitatif dengan menggunakan data sekunder berupa laporan keuangan perusahaan yang terdaftar di bursa efek Indonesia periode 2018-2021.Penentuan sampel dalam penelitian ini menggunakan purposive sampling.Analis data yang digunakan uji asumsi klasik dan analisis linier berganda.

Variabel independen yang digunakan dalam penelitian ini adalah pajak penghasilan badan (X1), current ratio (X2) dan kinerja perusahaan (X3), sedangkan variabel dependen return on asset (Y). Hasil penelitian menunjukkan bahwa ada pengaruh negative tetapi signifikan secara simultan dari pajak penghasilan badan, curreent ratio dan kinerja perusahaan terhadap return on asset pada perusahaan jenis consummer goods yang terdaftar di bursa efek indonesia. Dan ada pengaruh positif dan signifikan secara parsial kinerja perusahaan terhadap return on asset, sedangkan pajak penghasilan badan dan current ratio tidak berpengaruh signifikan secara parsial terhadap return on asset pada perusahaan jenis consummer goods yang terdaftar di bursa efek Indonesia periode 2018-2021
\end{abstract}

Kata Kunci: Pajak Penghasilan Badan, current Ratio, kinerja Perusahaan dan Return On Asset

\begin{abstract}
This study aims to determine the effect of corporate income tax, current ratio and company performance on return on assets in consumer goods industrial companies listed on the Indonesian stock exchange for the 2018-2021 period. This study is a quantitative study using secondary data in the form of company financial statements. which are listed on the Indonesia stock exchange for the period 2018-2021. The determination of the sample in this study uses purposive sampling. Data analysis used classical assumption test and multiple linear analysis.

The independent variables used in this study are corporate income tax (X1), current ratio (X2) and company performance (X3), while the dependent variable is return on assets (Y). The results showed that there was a simultaneous negative but significant effect of corporate income tax, current ratio and company performance on return on assets in consumer goods companies listed on the Indonesian stock exchange. And there is a positive and partially significant effect on the company's performance on return on assets, while corporate income tax and the current ratio have no partial significant effect on return on assets in consumer goods companies listed on the Indonesian stock exchange for the 2018-2021 period.
\end{abstract}

Keywords: corporate income tax, current ratio, company performance and return on assets 
Vol. 10. No. 1. Tahun 2022

\section{PENDAHULUAN}

Pada umumnya tujuan utama perusahaan besar maupun perusahaan kecil adalah untuk menghasilkan laba semaksimal mungkin (Harnanto, 2013). Laba sering digunakan sebagai suatu dasar pengenaan pajak, kebijakan dividen, pedoman investasi serta pengambilan keputusan dan unsur prediksi”. Disamping itu penghasilan yang didapat dari kegiatan usaha akan dikenakan pajak penghasilan badan yang telah diatur dalam "Undang-Undang No 16 Tahun 2009 Pasal 1 ayat 1 Tentang Ketentuan Umum dan Tata Cara Perpajakan, Pajak diartikan sebagai kontribusi wajib kepada negara yang terutang oleh orang pribadi atau badan yang bersifat memaksa berdasarkan UndangUndang, dengan tidak mendapatkan imbalan secara langsung dan digunakan untuk keperluan negara bagi sebesar-besarnya kemakmuran rakyat" ( Febrian dkk, 2018 ).

Pasar modal (Capital Market) adalah pasar untuk berbagi instrument keuangan jangka panjang yang bisa di perjual belikan, baiksurat hutang (Obligasi), Ekuity (saham), reksa dana, instrument driveative maupun instrument lainya. Pasar modal bisa dikatakan sebagai sarana pendanaan bagi perusahaan maupun intuisi lain dan sarana untuk kegiatan berinvesttasi. Di Indonesia lembaga yang terlibat di pasar modal adalah Bursa Efek Indonesia (BEI), didalam "Undang-Undang Republik Indonesia Nomor.8 tahun 1995 tentang pasar modal mendefinisikan pasar modal sebagai kegiatan bersangkutan dengan penawaran umum dan perdagangan efek yang di terbitkanya, serta lembaga dan profesi yang berkaitan dengan efek". (www.idx.co.id).

Laporan keuangan merupakan informasi yang paling dicari oleh para calon investor sebagai tolak ukur pertimbangan dalam pengambilan keputusan sebelum berinvestasi di pasar modal. Oleh karena itu perusahaan yang telah go public harus benar benar menunjukkan prestasi yang baik dalam kegiatan usahanya. "Rasio keuangan merupakan salah satu tolak ukur dalam tingkat prestasi baik buruknya kinerja suatu perusahaan" (Casanova dan Nindito 2014).

Profitabilitas menurut Anoraga (1997: 300) dalam Rahmah, dkk (2016) yaitu suatu gambaran kemampuan suatu perusahaan dalam mengasilkan keuntungan atau profit, yang beruhubungan dengan pendapatan, aktiva dan modal. Untuk menilai hasil kinerja perusahaan diukur dari besarnya reurn on asset, karena tinggi rendahnya tingkat return on asset akan mempengaruhi kinerja perusahaan tersebut. Berikut adalah indikator untuk mengukur kinerja keuangan, antara lain yaitu rasio likuiditas, profitabilitas, aktivitas, solvabilitas, pertumbuhan perusahaan dan nilai perusahaan. Rasio profitabilitas dapat diukur menggunakan beberapa rasio seperti profit margin, ROA dan ROE. Dalam penelitian ini proxi yang di gunakan adalah ROA dimana ROA merupakan alat untuk mengukur profitabilitas dengan mengukur laba bersih sesudah pajak setiap asset' (Return On Asset).

Pajak didefinisikan sebagai "iuran kepada kas Negara berdasarkan undangundang (yang dapat di paksakan) dengan tidak mendapat jasa timbale (kontraprestasi) yang langsung dapat di tunjukan dan yang di gunakan untuk membayar pengeluaranpengeluaran umum" (Supramono Damayanti 2015:2).

Perbedaan suatu prinsip dari perpajakan dan akuntansi dalam menyusun laporan keuangan dan koreksi fisskal terhadap adanya koreksi negatif maupun koreksi positif yang akan berpengaruh pada keuntungan. book-tax differences merupakan prinsip yang memiliki perberbedaan antar akuntansi prpajakan dalam menyusun laporan keuangan menyebabkan tingkat penghasilan kena pajak (laba fiskal) dan penghasilan sebelum pajak (laba akuntansi) menjadi penyebab terjadi perbedaan perhitungan laba menurut akuntansi dan perpajakan. Perbandingan antara taxable income (laba tahun berjalan) terhadap book income (laba akuntansi) disebut denganTaxto book ratio. Dengan menghitung ratio laba tahun berjalan dengan laba sebelum pajak merupakan cara untuk menghitung Tax to book ratio (Miranidia, 2016).

Marpaun dan Tjun (2016) "telah melakukan penelitian tentang pengaruh pajak tangguhan dan taxto book ratio terhadap kinerja perusahaan pada perusahaan manufaktur yang listing di BEI periode 20122013". Hasil bahwa variabelTaxto Book Ratio secara parsial tidak mempunyai pengaruh yang signifikan terhadap variabel kinerja perusahan, dan secara simultan Taxto 
Book Ratio dan pajak tangguhann tidak terdapat pengaruh yang signifikan terhadap kinerja perusahan. Berdasarkan hasil penelitian (Miranidia 2016) "dengan hasil bahwa taxto bookratio memiliki pengaruh yang signifikan terhadap profitabilitas pada tahun penelitian". Hal ini berbanding tebalik dengan hasil penelitian Harmana (2014) dengan hasil penelitiannya "tax to book ratio tidak berpengaruh terhadap dengan kinerja perusahaan dengan ROA (Return On Asset) sebagai indikator".

Likuiditas menunjukkan "kemampuan suatu perusahaan untuk memenuhi kewajiban keuangannya yang harus segera dipenuhi atau saat ditagih, sedangkan profitabilitas mengukur kemampuan para eksekutif perusahaan dalam menciptakan tingkat keuntungan baik dalam bentuk laba perusahaan maupun nilai ekonomis atas penjualan, aset bersih perusahaan maupun modal sendiri. Rasio likuiditas dapat diukur dengan menggunakan beberapa rasio seperti current ratio $(\mathrm{CR})$, quick ratio $(\mathrm{QR})$ dan cash ratio"(Hasmita 2015). Proxi variabel likuiditas yang di gunakan didalam penelitian ini yaitu current ratio (CR)dimana current ratio (CR) merupakan "rasio yang di gunakan untuk mengukur kemampuan perusahaan dalam membayar kewajiban jangka pendeknya dengan menggunakan aktiva lancar yang di miliki" (Sujarweni 2017).

Berdasarkan hasil penelitian dari Safitri (2017) terdapat hasil perhitungan dengan besaran nilai $\mathrm{t}$ hitung 0,801 dan signifikasi sebesar 0,431 jadi tidakterdapat pengaruh signifikan variabel CR (current ratio) terhadap variabel ROE (return on equity) pada perusahan sektor otomotif yang tercatat di BEI priode 2010-2013. Berbeda dengan hasil penelitian yang telah dilakukan (Rahmah, Cipta dan Yudiaatmaja 2016) "menunjukkan bahwa secara parsial Likuiditas terhadap Profitabilitas terdapat pengaruh yang positif dan signifikan pada Perusahaan Otomotif yang Terdaftar di BEI tahun 2012-2014". Hasil ini searah dengan penelitian yang dilakukan oleh Rima Astita (2013) "dapat dikatakan bahwa Likuiditas berpengaruh signifikan terhadap Profitabilitas".

Untuk mengetahui efektifitas suatu perusahaan dalam mengolah asetnya dapat menggunakan rasio aktivitas. Totall Aset Turnn Over (TATO) merupakan salah satu indikator untuk mengukur rasio aktivitas. TATO sebagai alat ukur efektifitas perusahaan dalam pemanfaatan aktivanya dalam menghasilkan laba (Hornne and Wacowics, JR. 1998:139). Dalam penelitian ini proxi yang di gunakan adalah TATO (Total Asset Turn Over), digunakan untuk mengukur kegiatan operaasional perusahaan serta menunjukan seberapa sering aktivanva berputar dalam suatu periode dengan rasio Total Asset Turn Over (TATO) (Sawir, 2009: 56).

Berdasarkan hasil penelitian dari Pradana (2018) "bahwa variabel aktivitas terdapat pengaruh positif dan signipikan terhadap variabel profitabilitas". Tidak sejalan dengan hasil penelitian dari (Jumiva 2019) "diperoleh nilai t hitung negatif sebesar 0,071 dan signifikansi sebesar 0,945 sehingga terlihat bahwa nilai signifikansi tersebut lebih besar dari 0,05 ". Artinya rasio aktivitas total asset turnover (TATO) tidak terdapat pengaruh secara signifikan terhadap rasio profitabilitas return on asset (ROA), sehingga hipotesis kedua ditolak. Hasil penelitian ini memiliki hasil yang sama dengan penelitian yang dilakukan oleh Ega Iskarisma (2017) "yang menyatakan bahwa tidak terdapat pengaruh total asset turnover terhadap return on asset".

Berdasarkan hasil penelitian (Rahmah, dkk 2016) "bahwa secara parsial Aktivitas terdapat pengaruh positif dan signifikan terhadap Profitabilitas pada Perusahaan Otomotif yang Tercatat di BEI periode 2012-2014". Hasil penelitian ini sejalan dengan hasil penelitian yang dilakukanoleh Handayani(2007) dan Nasrizal Akbar(2009) "dengan simpulan bahwa variabel aktivitas terdapat pengaruh positif dan signifikan terhadap profitabilitas".

Dari hasil berbagai penelitian terdahulu yang memiliki hasil yang berbeda memberikan refrensi untuk melakukan penelitian kembali dengan variabel independen variabel pajak (taxto bookratio), likuiditas dan aktivitas perusahaan dan variabel dependen dengan profitabilitas yang sebelumnya telah diteliti oleh Marpaun dan Tjun (2016) "melakukan penelitian tentang pengaruh pajak tangguhan dan tax to book ratio terhadap kinerja perusahaan dengan 
hasil penelitian menunjukkanTaxto Book Ratio tidak ada pengaruh yang signifikan terhadap profitabilitas secara parsial". Hasil penelitian (Rahmah dkk, 2016) menunjukkan bahwa "secara parsial terdapat pengaruh variabel Likuiditas terhadap Profitabilitas yang signifikan pada Perusahaan Otomotif yang Terdaftar di BEI periode 2012-2014". Pradana (2018) dengan hasil bahwa variabel aktivitas memiliki pengaruh yang positif dan signifikan terhadap variable profitabilitas.

Maka rumusan masalah pada penelitian ini yaitu apakah pajak penghasilan badan, curren ratio dan kinerja perusahaan secara parsial berpengaruh dan signifikan terhadap return on asset pada perusahaan jenis consumer goods yang tercatat di bursa efek indonesia Tahun 2018-2021. Apakah pajak penghasilan badan, curren ratio dan kinerja perusahaan secara simultan berpengaruh dan signifikan terhadap return on asset pada perusahaan jenis consumer goods yang tercatat di bursa efek indonesia (BEI) Tahun 2018-2021

Tujuan penelitian ini adalah untuk mengetahui apakah pajak penghasilan badan, curren ratio dan kinerja perusahaan berpengaruh dan signifikan terhadap return on asset pada perusahaan jenis consummer goods yang tercatat di bursa efek indonesia (BEI) Tahun 2018-2021 baik secara parsial maupun simultan.

\section{LANDASAN TEORI \\ Return On Asset (Profitabilita)}

Profitabilitas yaitu rasio yang digunakan untuk mengukur kemampuan perusahaan dalam mencari profit atau keuntungan. Rasio ini juga memberikan ukuran tingkat efektifitas manajerial dalam suatu perusahaan. Hal ini di lihat dari tingkat laba yang dihasilkan dari penjualan dan pendapatan investasi.Wiagustini (2010:76) menyatakan "profitabilitas merupakan suatu kemampuan perusahaan untuk mewujudkan suatu keuntungan bagi perusahaan atau merupakan suatu pengukuran akan efektivitas pengelolaan perusahaan dalam mengelola manjemennya. Secara umum ada tiga jenis rasio profitabilitas yang dominan dipakai dalam penelitian yaitu profit margin, return on assets (ROA), dan return on equity (ROE)". ROA merupakan "salah satu indikator terbaik untuk mengukur kinerja perusahaan dimana ROA bisa ditentukan oleh serangkaian kebijakan perusahaan dan dipengaruh oleh faktor-faktor lingkungan tingkat profitabilitas perusahaan yang tinggi menunjukkan kinerja manajerial perusahaan yang baik" (Sanjaya dkk, 2015).

Perbandingan rasio antara laba fiskal dan laba akuntansi dimana laba fiskal berlandaskan pada peraturan undang-undang perpajakan yang berlaku di Indonesia sedangkan laba akuntansi berlandaskan pada standar akuntansi keuangan yang digunakan di Indonesia di sebut dengan Taxto bookratio. "Taxto book ratio dapat dilihat dengan menghitung ratio laba fiskal terhadap laba sebelum pajak dalam (Miranidia, 2016).

\section{Curren Ratio (Likuiditas)}

Likuiditas merupakan "rasio yang mengukur kemampuan perusahaan dalam melunasi hutang jangka pendeknya" Hery (2017:283). Untuk mengetahui apakah perusahan mampu dalam memenuhi utang jangka pendeknya jangka waktu tertentu yang diperoleh dari pemberi pinjaman dengan menggunakan rasio ini. Rasio likuiditas yang dipergunakan adalah Curent Ratio (CR), CR digunakan untuk mengukur kemampuan perusahaan dalam membayar utang jangka pendek yang akan jatuh tempo. Menurut Wiratna Sujarweni (2017:60).

\section{Kinerja Perusahaan}

Kinerja perusahaan merupakan "rasio yang mengukur seberapa baik dan efisien perusahaan dalam memanfaatkan asetnya. Dalam mengetahui efisiensi dan efektivitas perusahaan dalam pemanfaatan aktivanya didalam menghasilkan penjualan menggunakan indikator TATO" (Horne and Wachowic, JR.1998:139). Rasio ini menggambarkan bagaimana perputaran asset dalam periode tertentu atau mengukur seefektif apa aktiva yang digunakan dalam opersional suatu perusahaan (Sawir, 2009: 56).

\section{METODE PENELITIAN}

Dalam penelitian ini metode penelitian yang digunakan adalah metode kuantitatif yang dilakukan untuk menguji pengaruh dari variabel independen terhadap variabel dependen. Yang menjadi populasi dalam penelitian ini adalah semua perusahaan jenis consummer goods yang terdaftar di Bursa Efek Indonesia periode 
2018-2021. Sampel yang digunakan dalam penelitian ini yaitu Purposive Sampling. Adapun yang termasuk kriteria untuk memilih sampel dalam penelitian ini yaitu Perusahan jenis consummer goods yang listingdi BEI tahun 2018-2021, Perusahaan jenis consummer goods yang mempublikasikan laporan keuangan secara 4 tahun berturut-turut pada tahun 2018-2021, Perusahaan jenis consummer goos yang bergerak di bidang penjualan sparepart.Jenis data yang digunakan dalam penelitian ini adalah data sekunder yang bersumber dari laporan keuangan perusahaan periode 2018 sampai 2021 dan laporan keuangan tersebut diakses langsung dari situs resmi Bursa Efek Indonesia (www.idx.co.id). Dalam penelitian ini ada empat variabel yang akan diukur, yaitu varibel independen (X1) pajak penghasilan badan, (X2) curren ratio dan (X3) kinerja dan varibel dependen $(\mathrm{Y})$ yaitu return on asset. Pada variabel independen (X1) pajak penghasilan badan diproksikan menggunakan Taxto book ratio dapat dilihat dengan menghitung ratio laba fiskal terhadap laba sebelum pajak dalam" (Miranidia 2016). Perhitungannya adalah sebagai berikut :

Taxtobookratio $=\frac{\text { Tlit }}{\text { PTBlit }}$

Keterangan :

Tlit = Laba kena pajak atau laba fiskal pada perusahan

PTBIit = Laba sebelum pajak atau laba akuntansi pada perusahan

Dalam penelitian ini peneliti menggunakan current ratio (CR)sebagai proxi variabel curren retio (X2) dimana current ratio (CR) merupakan rasio yang di gunakan untuk mengukur kemampuan perusahaan dalam membayar kewajiban jangka pendeknya dengan menggunakan aktiva lancar yang di miliki (Sujarweni 2017). Current Ratio dapat di hitung dengan rumus :

CerrentRatio $=\frac{\text { Aktiva lancar }}{\text { Hutang lancar }}$

Kinerja bisa diukur menggunakan Total Asset Turn Over (TATO). TATO mengukur efisiensi relatif perusahaan terhadap pemanfaatan aktiva dalam menghasilkan penjualan (Horne and Wachowics, JR. 1998: 139) dalam (Pradana 2018).Sujarweni
(2017)Rasio ini dapat di hitung dengan rumus yaitu:

Totalassetsturnover $=\frac{\text { Penjualan bersih }}{\text { Total aktiva }}$

Sedangkan unruk variabel (Y) Return On Asset dalam penelitian ini diukur dengan return on assets (ROA), yaitu mengukur kemampuan menghasilkan laba melalui pengoprasian aktiva yang dimiliki pada masing- masing perusahaan dalam sektor otomotifdi BEI tahun 2018 - 2021 dengan rumus yang dikemukakan oleh (Wiagustini, 2010:81). ROA $=\frac{\text { lababersihsetelahpajak }}{\text { Totalaktiva }}$

\section{HASIL DAN PEMBAHASAAN}

Pengaruh Pajak Penghasilan Badan terhadap Return On Asset

Hipotesis pertama menunjukkan bahwa pajak penghasilan badan tidak berpengaruh terhadap $\mathrm{R} \quad \mathrm{O}$ A pada perusahaan jenis consummer goods di BEI. Hasil uji $t$ untuk variabel bebas pajak penghasilan badan sebesar 2,008 dengan nilai signifikansinya 0,055 lebih besar dari tingkat kekeliruan $5 \%(a=0,05)$ maka dapat diambil kesimpulan untuk menolak H1. Artinya pajak penghasilan badan secara parsial tidak berpengaruh signifikan terhadap returen on aset. Hal ini tidak sejalan dengan penelitian Miranidia (2016) yang mengatakan bahwa tax to book ratio berpengaruh secara signifikan terhadap return on aset perusahaan. Sedangkan Marpaun dan Tjun (2016) dengan hasil penelitian menunjukkan Tax to Book Ratio tidak mempunyai pengaruh yang signifikan terhadap return on aset secara parsial. Dari hasil ini dapat dijadikan pertimbangan bagi investor yang menanamkan modalnya terhadap perusahaan sebelum memutuskan untuk berinvestasi. "Tax to book ratio dapat dilihat dengan menghitung ratio laba setelah pajak terhadap laba sebelum pajak" (Miranidia 2016). Artinya bahwa Taxto book ratio dapat berkontribusi tehadap profitabilitas dimana di dalam perhitungan kedua rasio ini sama sama menggunakan laba setelah pajak dalam perhitunganya.

\section{Pengaruh Curren Ratio terhadap Return On Asset}

Hipotesis kedua menunjukkan bahwa curren ratio tidak berpengaruh terhadap return on asset pada perusahaan jenis 
consummer goods di BEI. Hasil uji t untuk variabel bebaslikuiditas sebesar 0,354 dengan nilai signifikansinya 0,726 lebih besar dari tingkat kekeliruan $5 \%(\mathrm{a}=0,05)$ maka dapat diambil kesimpulan untuk menolak $\mathrm{H} 2$. Artinya curren ratio tidak berpengaruh signifikan terhadap return on asset. Penelitian ini sejalan dengan penelitian yang dilakukan oleh Rachmalia (2013)Berdasarkan hasil penelitian menggunakan SPSS dihasilkan rasio lancar pada perusahaan dagang tidak mempunyai pengaruh dignifikan terhadap profitabilitasnya baik secara simultan dan parsial karena hasil nilai signifikan pada uji $\mathrm{F}$ dan uji t untuk rasio lancar masing-masing sebesar 0,267 dan 0,654 nilai tersebut lebih besar dari 0,05. Sedangkan (Rahmah, Cipta dan Yudiaatmaja 2016) menunjukkan bahwa ada pengaruh positif dan signifikan secara parsial Likuiditas (X) terhadap Profitabilitas (Y) pada Perusahaan Otomotif yang Terdaftar di Bursa Efek Indonesia periode 2012-2014. Dapat disimpulkan bahwa seberapa besar pengaruh rasio lancar terhadap profitabilitas perusahaan tidak selalu sama pada tiap perusahaan. (Kasmir, 2016:129) "Semakin tinggi likuiditas perusahaan maka profitabilitas semakin rendah". Dengan demikian hipotesis yang menyatakan bahwa rasio likuiditas tidak berpengaruh secara parsial terhadap profitabilitas pada perusahaan sektor otomotif terbukti kebenarannya.

\section{Pengaruh Kinerja perusahaan terhadap Return On Asset}

Hipotesis ketiga menunjukkan bahwa kinerja perusahaan berpengaruh positif terhadap return on asset pada perusahaan jenis consummer goods di BEI. Hasil uji t untuk variabel bebasaktivitas sebesar 4,347 dengan nilai signifikansinya 0,000 lebih kecil dari tingkat kekeliruan 5\% $(\mathrm{a}=0,05)$ maka dapat diambil kesimpulan untuk menerima H3. Artinya kinerja prusahaan berpengaruh positif terhadap return on aset. Kinerja perusahaan dianggap mampu mempengaruhi return on asset karena semakin tinggi tingkat kinerja perusahaan maka akan semakin besar peluang perusahaan mendapatkan keuntungan yang dapat dimanfaatkan untuk mencapai tujuan perusahaan. Hal ini sejalan dengan penelitan yang dilakukan oleh Pradana (2018) yang mengakatan bahwa Rasio aktivitas mempunyai pengaruh yang positif dan signifikan terhadap variabel profitabilitas. Hal ini di karenakan TATO memiliki koefisien regresi yang positif sebesar 0,223660 dan probabilitas sebesar 0,0000 dengan tingkat signifikansi $5 \%$. Profabilitas $0,0000<0,05$ sehingga variabel TATO mempunyai pengaruh yang signifikan terhadap variabel profitabilitas. Sedangkan (Jumiva dkk 2019) dengan hasil diperoleh nilai t hitung negatif sebesar $-0,071$ dan signifikansi sebesar 0,945 sehingga terlihat bahwa nilai signifikansi tersebut lebih besar dari 0,05. Artinya rasio aktivitas total asset turnover (TATO) tidak berpengaruh secara signifikan terhadap rasio profitabilitas return on asset (ROA). TATO mengukur efisiensi relatif perusahaan terhadap pemanfaatan aktiva dalam menghasilkan penjualan (Horne and Wachowics, JR. 1998: 139). Jadi aktivitas perusahaan yang efektif dan efisien dapat mempengaruhi besar kecilnya pendapatan suatu perusahaan.

Pengaruh Pajak penghasilan Badan, Curren Ratio dan Kinerja Perusahaan terhadap Return On Asset

Hasil pengujian secara simultan atau uji $F$ variabel independen yaitu pajak penghasilan badan(X1), Curren Ratio (X2) dan Kinerja perusahaan (X3) secara bersamasama memiliki pengaruh secara simultan terhadap variabel dependen yaitu return on asset pada perusahaan jenis consummer goods yang terdaftar di BEI periode 20182021. Dari hasil uji F diketahui bahwa nilai signifikan $\mathrm{F}$ sebesar $0,001^{\mathrm{b}}$ lebih kecil dari 0,05 maka H0 ditolak dan Ha diterima. Dari hasil ini dapat di simpulkan bahwa variabel independen Pajak penghasilan badan, curren retio dan kinerja perusahaan secara simultan atau bersama-sama berpengaruh signifikan terhadap return on asset, jadi dapat di simpulkan bahwa $\mathrm{H} 4$ diterima. Sesuai dengan hasil uji f yaitu pengujian terhadap koefisien regresi sacara simultan (Sugiyono).Pengujian ini dilakukan untuk mengetahui semua variabel independen yang terdapat di dalam model secara simultan terhadap variabel dependen.

\section{KESIMPULAN DAN SARAN Kesimpulan}

Berdasarkan hasil penelitian dari persamaan regresi linier berganda mengenai pengaruh variabel independen Pajak 
penghasilan badan (X1), curren ratio (X2) dan kinerja perusahaan (X3) terhadap variabel dependen Return On Asset (Y) dapat disimpulkan bahwa:

1. Rasio pajak penghasilan badan secara parsial yang diproksikan dengan tax to book ratiotidak berpengaruh signifikan terhadap return on asset pada return on asset (ROA). Hasil uji t untuk variabel pajak sebesar 2,008 dengan nilai signifikansinya 0,055 lebih besar dari tingkat kekeliruan $5 \%(a=0,05)$ maka dapat diambil kesimpulan untuk menolak H1. Artinya pajak penghasilan badan secara parsial tidak berpengaruh signifikan terhadap return on asset ( ROA )

2. Rasio curren ratio Secara parsia yang diproksikan dengan current ratio (CR) tidak memiliki pengaruh yang signifikan terhadap return on asset pada return on asset (ROA). Hasil uji t untuk variabel bebaslikuiditas sebesar 0,354 dengan nilai signifikansinya 0,726 lebih besar dari tingkat kekeliruan 5\% $(\mathrm{a}=0,05)$ maka dapat diambil kesimpulan untuk menolak H2. Artinya curren ratio tidak berpengaruh signifikan terhadap return on asset

3. Rasio kinerja perusahaan Secara parsial yang diukur dengan total asset turnover (TATO) terdapat pengaruh yang signifikan terhadap return on asset pada return on asset (ROA). Hasil uji t untuk variabel kinerja perusahaan sebesar 4,347 dengan nilai signifikansinya 0,000 lebih kecil dari tingkat kekeliruan 5\% $(a=0,05)$ maka dapat diambil kesimpulan untuk menerima H3. Artinya aktivitas berpengaruh positif dan signifikan terhadap return on asset ( ROA ).

4. Secara simultan variabel independen Pajak penghasilan badan, curren ratio, dan kinerja perusahaan dari hasil uji $\mathrm{F}$ diketahui bahwa nilai signifikan $F$ sebesar $0,001{ }^{\mathrm{b}}$ lebih kecil dari 0,05 maka H0 ditolak dan Ha diterima. Dari hasil ini dapat di simpulkan bahwa variabel independen Pajak penghsilan badan, curren ratio ( $\mathrm{CR}$ ), dan kinerja perusahaan secara simultan atau bersama-sama berpengaruh signifikan terhadap Return On Asset ( ROA )
Saran

Berdasarkan hasil penelitian dan kesimpulan diatas, ada beberapa saran yang dapat diberikan oleh penulis yaitu:

1. Untuk Peneliti selanjutnya juga dapat memperluas ruang lingkup penelitiannya, tidak hanya pada perusahaan jenis consummer goods namun juga pada perusahaan di sektor-sektor lainnya yang terdaftar di Bursa Efek Indonesia seperti perusahaan jasa, sektor keuangan atau perbankan, dan lainnya.

2. Untuk penelitian selanjutnya dapat menambahkan jumlah tahun penelitian dan juga dapat mengggunakan variabel lain yang berpengaruh terhadap return on asset yang tidak di teliti dalam penelitian ini seperti, Pajak penghasilan badan, curren ratio dan kinerja perusahaan.

\section{DAFTAR PUSTAKA}

Amrina, Astrina. (2018). Pengaruh profitabilitas dan ukuran perusahaan terhadap pengungkapan tanggungjawab sosial pada perusahan asuransiyang terdaftar di bursa efek Indonesia.Jurnal penelitian dan pengembangan akuntansi (vol.12 no.1 Januari 2018).

Anoraga, Panji. 1997. Manajemen Bisnis. Cet1. Jakarta: Rineka Cipta.

Febrian,Wahyudi dan Subeki.2018."Analisis Pengaruh Perencanaan Pajak Dan Beban Pajak Tangguhan Terhadap Manajemen Laba (Studi Kasus Pada Perusahaan Manufaktur Yang Tercatat Di Bursa Efek Indonesia)".Jurnal Penelitian Dan Pengembangan Akuntansi Vol.12 No.2 Juli 2018.

Harahap, Sofyan Syafri.2009. Analisis Kritisatas Laporan Keuangan. Jakarta: PT Raja Grafindo Persada

Harmana, Dwi. 2011. "Pengaruh Pajak Tangguhan Dan Tax To Book Ratio Terhadap Kinerja Perusahaan". EJurnal Akuntansi Universitas Udayana. Vol. 6 No. 3 
http://www.idx.co.id

Jumiva dkk. 2019.”Analisis Pengaruh Likuiditas Dan Aktivitas Terhadap Profitabilitas Pada Perusahaan Food And Beverages Yang Terdaftar Di Bursa Efek Indonesia (Bei)Tahun 2013-2017'.Fakultas Ekonomi Universitas Islam Majapahit Mojokerto.

Marpaung, Tjun. (2016)."Pengaruh Pajak Tangguhan dan Tax to Book RatTerhadap Kinerja Perusahaan".Jurnal Akuntansi Vol.8 No.1 Mei 2016: 16 - 38 .

Miranidia.(2016). Pengaruh pajak tangguhan dan tax to book ratio terhadap profitabilitas dan persistensi laba.Sekolah Tinggi Ilmu Ekonomi Perbanas Surabaya 2016.

Pradana, Gilang Ari (2018). Analisis pengaruh rasio aktivitas, likuiditas, financial leverage dan firm size terhadap profitabilitas pada perusahaan tambang yang terdaftar di bei tahun 2013-2016.jurusan manajemen bisnis syariah fakultas ekonomi dan bisnis islam institut agama islam negeri surakarta 2018.

Priyatno, Duwi. 2012. Cara Kilat Belajar Analisis Data Dengan SPSS 20. Yogyakarta : Andi.

Rachmalia.(2013).analisis pengaruh likuiditas terhadap profitabilitas pada perusahaan dagang yang terdaftar di bei (2008-2012). Jurnal ilmiah manajemen dan akuntansi fakultas ekonomi (JIMAFE) vol.02 2013.
Safitri, Eka.(2017). Analisis Pengaruh Rasio Aktivitas, Likuiditas Dan Ukuran Perusahaan Terhadap Profitabilitas Pada Perusahaan Otomotif Yang Terdaftar Di Bursa Efek Indonesiatahun 2010-2013.Fakultas Ekonomi Dan Bisnis Universitas Lampung Bandar Lampung 2017.

Salamah, Pamungkas dan Yogi 2016. Pengaruh Profitabilitas Dan Biaya Operasional Terhadap Pajak Penghasilan Badan (Studi Pada Perusahaan Manufaktur Yang Terdaftar Di Bursa Fek Indonesia Periode 2012-2014)'.Jurnal Perpajakan (JEJAK) |Vol.9No.12016| perpajakan.studentjournal.ub.ac.id

Sanjaya, Sudirman dan Dewi.2015"Pengaruh Likuiditas Dan Aktivitas Terhadap Profitabilitas Pada Pt Pln (Persero".E-Jurnal Manajemen Unud, Vol. 4, No. 8, 2015.

Sawir, Agnes. (2009).Analisa Kinerja Keuangan dan Perencanaan Keuangan

Perusahaan.Jakarta : Gramedia Pustaka Utama. Dalam gilang ari 2018.

Sugiyono. 2013. Metodologi Penelitian Bisnis. CV. Bandung : Alfabet.

Sujarweni.2017. Analisis laporan keuangan. Yogyakarta

Widayanti,,Triaryati dan Abundarti 2016." Pengaruh Profitabilitas, Tingkat Pertumbuhan Perusahaan, Likuiditas, Dan Pajak Terhadap Struktur Modal Pada Sektor Pariwisata".E-Jurnal Manajemen Unud, Vol. 5, No. 6, 201 